\begin{abstract}
Drawing on Michelle Fine's (2006) vision for social psychology, I argue for radical archiving as a means for "bearing witness". In March 2013 the Center for Constitutional Rights filed a class action lawsuit against the New York Police Department for their racist "stop and frisk" practices. I was asked by two connected collectives to sit in on Floyd vs. City of New York and make a live and public documentation of it; Communities United for Police Reform asked me to do it "as an activist", the Public Science Project asked me to also bring my "critical psychological lens". How I did so was not planned - it was informed and it was unfolding. Two years on, I push the nascent literature on radical archiving to experiment with how this practice may not (just) offer scripts for the future but signs from an emancipated one. I argue that the reflexive demands of radical archiving make for conditions of instability that in turn welcome time-traveling moments of utopian potential co-constituted by the archiver and the archive - thereby bearing witness to a world that could be. The archive, then, is not a passive object of inquiry so much as an active, unruly companion for strengthening the response-ability of a critical and creative social psychology from the future.
\end{abstract}


Radical archiving as social psychology from the future

\section{Radical archiving as social psychology from the future}

\section{Radical archiving}

In 2006, Michelle Fine forecasted a "fictional textbook" that would "incite a re-membering, and re-thinking, of critical methods for the social psychological study of oppression and resistance" (p. 83). Asking how social research could "provoke greater awareness of injustice and contribute to social movements more intimately", Fine writes of a text that would remind us of the democratic and activist origins of social psychology, the struggle to be public individuals, and how social research can - indeed, should - be a tool of democratic engagement. She calls this book, Bearing Witness.

Here, I argue for radical archiving as one such method for bearing witness. Although the radical potential of the archive has been harnessed within activist and artistic communities for some time, it is only since the turn of the century that academics have come to recognize it as an explicitly political act. As Stuart Hall (2001) writes, the activity of archiving is "always a critical one, always a historically located one, always a contestatory one” (p. 92). Given the capacity for archives to (be used to) reinscribe hegemonic discourses, and thus the hierarchies on which an oppressive nation-state depends, Hall (2005) continues that reappropriating control over the "writing of one's own story" is to struggle for both a decolonization of the psyche and a cultural liberation. In other words, the archive is not just something that can be used for social movements, it can be a practice of social movement in and of itself.

Archives can thus be an example of what Andrew Flinn (2011) calls a "useful history". That is,

not history produced by and for disinterested academic research but rather archives and history that are explicitly intended to be used to support the achievement of political 
objectives and mobilization, as a means of inspiring action and cementing solidarity ( $\mathrm{p}$. 12).

Flinn's description resonates with the vision of artists Chitra Ganesh and Mariam Ghani (2014) collaborators on Index of the Disappeared, an archive of post-9/11 policies and their effects. In their co-organization of Radical Archives - a public conference held in New York City (NYC) during October, 2014 - Ganesh and Ghani depict three ways in which archives/archiving can do radicality: when of radical politics and practices, when radical in form or function, and when done during moments or contexts when archiving itself becomes a radical act (see also Ghani, 2015, for further consideration of these forms).

In March 2013, I - a PhD candidate in critical social psychology and an activist involved in actions that creatively question surveillance - agreed to undertake a live and public documentation of a ten-week court trial on police racism in NYC. In what follows I draw on my experiences to consider the possibilities of a radical archival practice for Fine's (2006) social psychology from the future.

\section{Watching Floyd}

In July 2014, Eric Garner - a 43-year-old Black man and father of six - died after being placed in an illegal chokehold by New York Police Department (NYPD) officers for selling cigarettes on the streets of Staten Island. Garner's death, and the failure to indict the officers involved, triggered media attention and citywide protests; an outrage intensified by the subsequent fatal shooting in Ferguson, Missouri, of Michael Brown, an 18 year old Black man from St Louis, thereby consolidating a nationwide movement to stop police brutality against communities of color known as Black Lives Matter.

While the public(ized) ghosts of this powerful contemporary resistance, Garner and 
Brown are by no means the lone figures of police racism in the US. Their killings come soaked in a legacy of discriminatory policing practices that disproportionately target black men and disproportionally use excessive force. As documented by Michelle Alexander (2010), this pastpresent-future emerges from, and sustains, the supremacy of white elites; creating a racialized caste system - "the new Jim Crow" - in which Black communities are exploited and/or eradicated in the name of "criminal justice".

While police murders and mass incarceration are two of the more explicit techniques in this American apartheid, these are lubed by more banal, everyday tactics arising from "quality of life" or "broken windows" policies aiming for a style of policing that is supposedly preventative. Seemingly common sense, this logic moves within contemporary politics of terror that draw on a post-9/11 milieu wary of potential threats (Massumi, 2010); a fear-full suspicion that rationalizes a stalking of neighborhoods and bodies that are considered more likely to be criminal. The violent histories, politics, and effects of this assumption have been documented and disrupted by Black scholars for decades (see this year's symposium issue in the Ohio State Journal of Criminal Law on "Critical race theory and criminal justice" - guest edited by Bennett Capers for just a handful of more recent examples), exposing the role of slavery, imperialism, and colonialism in shaping the contemporary neoliberal security state (e.g., Alexander, 2010; Browne-Marshall, 2013).

One of the most prolific of these banal, everyday tactics is "stop and frisk". Technically "stop, question, and frisk", police policy allows officers to stop and question any person whom they reasonably suspect has committed, is currently committing, or is about to commit a crime. If they then think that the person is also carrying a weapon, they may frisk them in the name of officer safety. Between January 2004 and June 2012, the NYPD conducted over 4.4 million such 
stops. Approximately 85 percent of people stopped were Black or Latino, even though these groups represent only 52 percent of the city's population. Moreover, only approximately 10 percent of stops led to any further law enforcement action, with weapons being recovered only a minute fraction of the time (Center for Constitutional Rights, 2013). Echoing the enduring experiential expertise of communities of color, these numbers suggest that - as the Center for Constitutional Rights (CCR) puts it - the NYPD use "race as a proxy for crime" (Zamani, 2015, p. 2). And so from March 2013, after fifteen years of challenging police racism and brutality, CCR took the NYPD to court. A class action litigation, Floyd v. City of New York led to a federal court judgment that held the NYPD liable for "a widespread practice of unconstitutional and racially discriminatory stop and frisks" (Zamani, 2015, p. 2).

The strength of CCR's action was dependent upon a number of local and national advocacy groups including Communities United for Police Reform (CPR) - a movement of community members, lawyers, researchers and activists to end discriminatory policing practices in NYC. One element of this movement is the Public Science Project (PSP) - a collective of academics, students, community members, lawyers, artists, and activists committed to using participatory and critical research methods in the struggle for a just world. Since its beginnings over a decade ago, PSP has positioned itself as a response to the conditions of the neoliberal security state, including what it means to live under surveillance. For example, in 2011 they started collaborating with neighborhood residents in the South Bronx - a predominantly Black neighborhood in NYC - to collectively document community experiences of policing over a 40block area, thus forming the Morris Justice Project.

It was through my relationship with the Morris Justice Project that I was asked to sit in on Floyd and blog about it. Well aware of the politics of documentation as well as the exclusivity 
of court proceedings, CPR had been looking for an alternative to the court transcripts, media accounts, and legal reports that would otherwise represent the trial. Specifically, they wanted someone to do it "as an activist"; PSP also added that they would like someone to use a "critical psychological" lens. To me, the latter meant committing to constructing an account of the trial that was attuned to both the content and context of the courtroom - observing racialized and gendered relations of power; making connections with "other" social institutions, histories, issues, and current events; analyzing discursive, affective, and imaginal currents; unpacking assumptions, effects, and silences. As an activist, I also made sure that I was sharing details of the proceedings; contemplating implications for change; showcasing moments of resistance, protest, and difference; risking questions, outrage, creativity, and playfulness.

Thus, I braided the systemic gaze of critical race, feminist, and security scholars with my own feelings, dreams, and intuitions as well as the stories, statistics, images, ghosts, and coincidences offered by the space in and around 500 Pearl Street. Each day I sat in the courtroom taking notes, each lunchtime I texted possible tweets to CPR, each night I typed at my computer, each morning I sent my drafts to PSP for proof-reading and posting. One hundred hours of spectating - six note-books, ten pens, two highlighters, 20,000 words, and 50 images - later, and the emerging archive, Watching Floyd, contains a pattern of frustrations that throw a tired glare on the interconnected ignorances of the "justice" system: the whiteness of the space and process; the denial of histories and politics in "interpersonal" interactions; the imperialism of "reasonable" and "the individual"; the violence of jargon, detail, and boredom; the limited/ing nature of "evidence"...

Day 7, Thursday March $28^{\text {th }}$ 
After smiling politely through routine comments about needing to remove my boots for the courthouse metal detector yesterday morning, I was so busy admiring my hole-less stockings that I was taken completely off-guard when one of the security personnel appeared in front of me, reached above my naval, and took hold of the long necklace I was wearing - a small leather pouch filled with oh-so-mystical things, known as a 'medicine bag'.

(Freud would love this, btw.)

Weirdly mimicking an image from a dream I had had the night before, I was stunned staring at my sacred pouch sitting in his hand. The officer - an older white man proceeded to tell me how "tribes in Puerto Rico" wear these to "ward off witches", but then paused. Pulling gently so that the leather string pressured the back of my neck, he did not (would not) finish schooling me until I looked him in the eye.

There is a lot of manufactured eye contact from security in these parts. I get the sense that people are not only establishing power, but also trying to see if we are nervous. Furtive even. But there was something about the intimate intimidation of this particular banal interaction that is still sticking to me forty hours later as I write up this post. My body (soul) put in its place, or else...

It came just after I had watched a young, white, power-suited, femme, cis-gendered woman also go through security. Taking off her belt and her high heels, sexualized in the name of 'safety'. She was going up for a job interview, and came into my mind as I was contemplating the exceptionally heteronormative defense team for this morning. (I seriously wondered at one point if all the wedding rings were strategically placed.) There is something poetic about these representatives of The City - these NYPD lawyers having bodies that defend the status quo.

While glaring in the process and space itself, the surveilling and policing of gender has yet to be officially witnessed in the trial content thus far. This is despite that a 2009 survey from the Welfare Warriors with 171 LGBTGNC (gender non conforming) New Yorkers - the vast majority of whom also identified as people of color - found that 54 percent had been stopped, 47 percent arrested, 29 percent strip searched, and 19 percent physically assaulted by police in the previous two years. And these actions were much more likely to happen to people who were transgender or two-spirit identified, or female identified.

So you can imagine my joy today, when the court was packed with queers. The large and exceptionally punctual crowd could not have been more timely and needed; reminding us that gender circulates with race through the prison industrial complex.

Together we sat through the revelation of more holes in NYPD bureaucracy. It was frustrating and tedious to be shown - over and over again - that officers either do not do their paper work around stop \& frisks, or they do so incorrectly, if not dishonestly. 
All under the supervision of commanding officers. Sergeant Kelly for example, admitted that officers under his command, and himself, have "violated NYPD policy" in how they (in)complete their 250s and/or memo books, including with regard to David Floyd's stop. As commented by Officer Joyce, "practice", (as opposed to policy), "means you do it every so often".

And when the Judge asked him what it means to "review" a 250, Kelly replied, "just that I read it". No one looks into the checked boxes; "reasonable suspicion" is left empty. And therefore fill-able. While deciding just today to add that he had also thought Floyd was 'casing the joint' and had a 'suspicious bulge' (both unverified by his partner Officer Hernandez and supervisor Kelly), Joyce's original 250 for the stop transformed jostling the doorknob into "Furtive movement", and having an out-of-state ID into "Evasive, false, or inconsistent responses to officers' questions".

Meanwhile (and objected - and overruled - by the defense lawyers for inclusion), all that Joyce could remember with regard to Floyd's physical description was that he was "Black". No height, weight, hair style, clothing. Nothing. Indeed, in a sworn statement to the CCRB, Joyce described "half the Bronx" as looking like the plaintiff.

The 250 becoming a visceral - albeit paper - indicator of Franz Fanon's argument that classification is akin to imprisonment.

Joyce also could not remember or recall the name of the area where the stop happened, what the residence looked like, where the car was stopped, what (if anything) was discussed with his colleagues before approaching Floyd, the details of the 'crime pattern' they were "trying to hit" at the time, and any of the other forms he completed. All this from an officer who, when asked if it was "difficult to see crime happening" on patrols, replied, "no ... we just had a sense ... we could just tell".

Joyce's 'lack' of memory did nothing to legitimate any faith one might have in police powers of observation. (Or, their respect for the justice system.) Same goes for the consistent inconsistencies between his account and those of Hernandez and Kelly. Including (ironically) about whether or not they had spoken with each other about this lawsuit - Joyce said at least five times, Hernandez said none.

One thing these officers did agree on, however, was Floyd's stop as "ending well". Yes a young man of color was yelled at, put against the wall, and frisked by three NYPD officers for trying to help his neighbor get into his house with keys. But after he was "good to go", "everybody was happy".

Everybody? Are the NYPD really so disconnected from the effects of their actions?

During lunchtime the courtyard outside 500 Pearl Street echoed with, "As a queer person of color, this trial matters a lot to me!" New York City Anti-Violence Project, the Audre Lorde Project, FIERCE, and the LGBTQ community of Make the Road $\underline{\mathrm{NY}}$ and $\underline{\text { Streetwise \& Safe, }}$, were having a press conference. The persistent and passionate 
resistance of these organizations to NYPD brutality captured perfectly on the back of someone's blue hoodie: "We are powerful because we have survived".

I could hear the action continue as I stood in line to cross the border back into the bleached courthouse. Awkwardly holding coffees and feeling like I was entering the wrong place, I wondered if the folks outside would be allowed back in to $15 \mathrm{C}$ or sent to the over-flow room - the designated place in this trial for bodies deemed excess.

It was eerily empty in the courtroom all afternoon.

\section{Day 21, Friday April 19}

Just as I was turning off my phone to head into the courthouse this morning, an article on Boston dropped into my Inbox. One 'bomber' killed, his little brother being 'hunted', the community on 'lockdown'. As I showed my ID (a new - post-Boston - procedure) and stripped for the scanners, the security guard told me that the little brother had since been surrounded somewhere - bombs wrapped around his body and a pile of assault rifles at his fingertips.

Overwhelmed that this was all going on in our same time-thread, when I arrived on the fifteenth floor and the courtroom bouncer asked how I was doing, all I heard myself say was, "I feel really sad". Soon joined by the second bouncer, the three of us talked at length about the bombings and the bombers. They are afraid of "the Muslims". I am afraid of their fear.

With no one else waiting to go in, the space was eerily quiet; our soft-spoken, conflicting words had a loud echo. I could see US flags flying half-mast through the windows around us - symbolizing sorrow, respect, and the looming threat of increased violence toward Muslim (or presumed Muslim) communities. Later I watched as a plane cast a large moving shadow over these flags and the beautifully messy rooftops of downtown Manhattan, and thought of the black water towers that I had seen when in Palestine. Blanketing the houses so that families could share their extremely limited access to the water supply, they had looked like crows.

\section{Watching.}

Leroy Downs had been on the stand all morning - a tall, gentle, 35yo black man in his thirties wearing a suit and spectacles. After walking home from his job as a substance abuse counselor, Downs was outside his house talking on the phone with a hand-held mouthpiece when an unmarked police car drove past, stopped, reversed, and spat out two white plainclothes cops. No cigarette, no smoke, no smell, they approached Downs saying, "Hey buddy, you look like you're smoking weed!" and pushed and pinned him up against his fence - frisking him, emptying his pockets, and going through his wallet. After finding nothing but cookies, the officers laughed when Downs asked for their badge 
numbers - saying he was "lucky they didn't lock him up" and that they were "just doing their fucking job".

Downs went straight to the precinct. After hours of being blocked from filing a complaint, he took a photo of the officers' car, walked home feeling "frustrated and angry", and filed one online with the CCRB. He was subsequently sent to the Citizens Police Academy.

Ten months of retraining on how to be policed?

Meanwhile the officers, as Judge Scheindlin pointed out, had "said under oath that none of this ever happened". "Troubled", she ordered the defense team to immediately recall them. They panicked - smelling perjury. Three hours later, instead of the officers, two large-burley-broad-suited-white-older men entered the courtroom and began to aggressively and arrogantly argue with the Judge. They were "independent lawyers" trying to suggest that she was violating the officers' rights. She fought back, saying "obviously you are worried about them being identified by Mr Downs" and telling them that if they did not comply with her order she would hold them for contempt of court.

A little shaken, the Judge asked the court for a couple of minutes after the NYPD's hired goons had left. Her skinny older frame wrapped in a black robe up high behind the bench, it felt like she had re-entered her body after rising up. And we spectators sat there stunned, and impressed. The officers will come in on Monday.

David Ourlicht had also been in the courtroom witnessing this exceptionally powerful figure fight the NYPD (and patriarchy) for justice. He took the stand after Downs. A 25 yo from Manhattan, half black half white, wearing a suit and on crutches from a snowboarding accident - he was the first plaintiff to exude class privilege. Not that this provided him with any protection from police brutality.

Stop 1: Wearing a black down winter jacket, Ourlicht was heading home in Queens when a white male uniformed cop drove past in a three-wheeled police scooter and stopped in his path up the street. Officer Moran told us yesterday that he thought Ourlicht was "walking weird" and had an overly large "suspicious bulge". He asked where he was going, requested an ID, then touched him around his belt buckle. When Ourlicht asked Moran for his ID he was told, "Now you're getting the full treatment. Get against the wall". "Scared", "upset", and "in disbelief", Ourlicht put his hands against the wall and spread his legs as Moran unpacked his suspicious bulge - keys, phone, wallet, passport, large 5-subject notebook, pens, paper, I-pod - throwing it all on the ground. Responding to the subsequent summons for disorderly conduct, Ourlicht said, "That's fucked up. You think I'm some young punk kid and you can treat me like this, but I'm not. I'm going to fight this".

"Yeah yeah I love it when you guys try to fight. You never win". 
Stop 2: This time with a friend, Ourlicht was heading to his parents' house for dinner, wearing the same jacket but with only his phone, keys, wallet, passport, and a small bottle Advil in the pockets. An undercover police car with four white male plain-clothed officers pulled up, windows wound down, saying they were looking for guns, and asking Ourlicht for ID. Getting out of the car, they told him to back up against the fence and simultaneously surrounded, questioned, frisked, and searched him. Saying over and over again, "We don't care about bullshit drugs, all we care about is guns".

Meanwhile his friend - his white friend - was standing ten feet away, talking face-to-face with one of the officers and showing his ID. Ourlicht watched out of the corner of his eye as the officer reached into his friend's pocket, pulled out a small bag of marijuana, said "Look what I found!", put it back, and then join his three colleagues in a second and even more "aggressive and thorough" search of Ourlicht. Going into all his pockets, putting their hands inside the waistband of his pants, running their fingers all around his zipper, feeling him up and down. And saying over and over again, "As soon as we find anything, we're arresting you".

They didn't. Walking away, his friend had his name called out and was told to "be more careful next time". Ourlicht on the other hand was left feeling "scared" - "It was nighttime, there was nobody around, my safety was in jeopardy".

Stop 3: Ourlicht had been spending the morning helping his friend - his black friend clean up his apartment in a public housing complex, when they went outside for a cigarette. Sitting in an enclosed space with other people from the building, two white male uniformed cops suddenly rushed in off the street, drawing their guns, and shouting, "There's a gun! Everyone get down on the ground!" Chin and forehead on the pavement, hands on the back of his head, Ourlicht saw a paddy-wagon-ful of white male uniformed cops pull up, jump out, and run in with their guns drawn. "Terrified", he was picked up by his belt, thumbed around the inside of his waistband, dropped to the ground.

Once again finding nothing, the officers looked at everyone's ID and then dismissed them - saying casually, "Sorry about that, we had reports of a gun in the area".

These everyday stories are ones of terror, and of apartheid. What struck me most about Ourlicht's testimony was his passport. An historic weapon in the violent policing of people's movements, homes, and subjectivities, it seemed like it was taken-for-granted that he needed to have identification on him at all times. Indeed, the knowledge and endurance that both Downs and Ourlicht displayed about NYPD practices today was extraordinary, and infuriating. Why should communities of color carry the burden of police brutality and police accountability?

Once more expected to service white supremacy.

Yet I left today filled with energy. There had been a mobilizing blend of dignity, laughter, anger, and comradery to the courtroom. I even found a lone trashcan on my way 
back to the train. After thinking on Tuesday that they had all been removed in a postBoston security move, it was an unlikely beacon in an otherwise terror-fied landscape.

These are two posts from Watching Floyd - the former made during the first week of the trial, the latter the last. I include them here in full as an illustration but not as a prototype; my process for Watching Floyd was not planned - it was informed and it was unfolding. And recording the practices of individuals and groups challenging police racism ("During lunchtime the courtyard outside 500 Pearl Street echoed with, 'As a queer person of color, this trial matters a lot to me!"”; "Downs went straight to the precinct"), prioritizing forms of knowledge and knowing usually marginalized in the courtroom ("Pulling gently so that the leather string pressured the back of my neck, he did not (would not) finish schooling me until I looked him in the eye"; "With no one else waiting to go in, the space was eerily quiet; our soft-spoken, conflicting words had a loud echo"), and critically documenting a system at the center of the neoliberal security state ("No one looks into the checked boxes; 'reasonable suspicion' is left empty. And therefore fill-able"; "Getting out of the car, they told him to back up against the fence and simultaneously surrounded, questioned, frisked, and searched him”, Day 21) - it accidentally created an archive of the trial, indeed a radical one (Ganesh \& Ghani, 2014).

Deriving from the Latin radix, the word "radical" etymologically points us to "the roots". Indeed, not suggested in the name of a mutually exclusive typology or exhaustive model, the above framework from Ganesh and Ghani (2014) presents possibilities for how one might engage in practices that animate, rather than cement, an archive. For Anthony Downey (2015), the recent call for doing so is at least in part a response to a contemporary moment defined by "the application of archival knowledge as an apparatus of social, political, cultural, historical, state and sovereign power" (p. 13, my emphasis). This definition of "the age we live in" is a 
reminder of the conservatism that can come through the construction of un-moving representations of the world, violently flattening both experience and possibility (Mohanty, 2003). As Ganesh and Ghani (2014) emphasize, a radical archive is one that is active in the present, documents the past, and offering scripts for the future.

Drawn to how these artists ultimately locate the radicality of the archive in its transtemporality, for the remainder of this essay I take inspiration from Gahesh and Ghani to interrupt a linearity that lingers in their ideas. I draw on my experiences of Watching Floyd to experiment with the possibility that this kind of practice may not (just) offer scripts for the future but signs from an emancipated one. I argue that radical archiving demands a reflexivity that creates conditions of instability which in turn welcome time-traveling - moments of utopian potential co-constituted by the archiver and the archive - and thus also bears witness to a world that could be, a world that echoes with Fine's (2006) social psychology from the future.

Time-traveling Nearly three decades ago, decolonial scholar Trinh Minh-ha (1989) declared, "In sight of every reader-by, let him run naked" (p. 47) before proceeding to expose colonialist knowledge-making practices, breaching the boundary between "the knower" and "the known" desired and required by imperialism. Her words echo within the contemporary US criminal justice system, emerging as it does from this same imperialist dynamic. Interrupting the anonymity of the writer-watcher is thus an important component of any anti-apartheid practice, including my own. As well as a descendent of settler ancestors and thus beneficiary of the racist relations taken to court, I am a descendent of intellectual ancestors - psychologists - who love to decide what or who is reasonable and what or who is not, and thus borne of the same imperialist logic lubricating the 
violence on trial in Floyd. It follows that, now also a scholar-activist, in Watching Floyd I needed to both make and undermine my own claims to truth.

I engaged this paradox through reflexivity. Given that Floyd was a case against race being used as a proxy for crime, against how one looks (in both senses of the word), making my eyes visible was a meaningful site of analysis and an unyielding political obligation (Pillow, 2003; Smith, 2013). When writing these pieces, my audience very much included people who do not know what police racism feels like; people who may not (want to) believe it, people who may (want to) believe it but do not (want to) know it is about them, too - all symptoms of the epistemologies of ignorance (Tuana, 2004) lubricating white supremacy. My opportunity to speak directly to this audience - especially as a white person myself - thus meant that I had what Erika Apfelbaum (2001) calls an “imperative to tell”. As Fine writes, In unjust societies, everyone is an insider. In systems of domination, no one is free of contamination. There are no bystanders, no witnesses and no positions of neutrality. Persons who benefit from social arrangements, and persons who 'merely' watch, are affected by and affect the social systems in which some unduly suffer. (p. 93)

I was certainly not "just" a spectator in this trial, and neither were any of the people reading my posts. Watching Floyd required interweaving a critical analysis that lifted up the ways in which imperialism affects a diverse range of experiences inside and outside the courtroom, moving toward what Chandra Talpade Mohanty (2003) calls an "imagined community" of people with “divergent histories and social locations, woven together by the political threads of opposition to forms of domination that are not only pervasive but also systematic" (p. 46-7).

Mohanty's “threads of opposition” is key here; witnessing resistance is essential to any radical project. For Watching Floyd this meant lifting up the knowledge, solidarity, research, and activism of individuals and groups committed to disrupting police racism, particularly those that make up the communities under siege. Indeed to not do so is to risk the production of "suffering 
bodies" that decolonial scholars have critiqued within Western imperialist projects (e.g., AbuLughod, 2002); depicting an unknowing, powerless object against an all-knowing, powerful subject of critique (Spivak, 1988) - in this case, oppressed black bodies against my own liberated white gaze - would be to reinscribe the very hierarchies I avowedly challenge, foreclosing possibilities for change.

Such foreclosure is especially significant when writing an essay on critical methods in social psychology given Eve Sedgwick (2003)'s argument that the "hermeneutics of suspicion" in which we (critical scholars) have been trained has had an "unintentionally stultifying side effect" (p. 124): the "privileging of paranoia". As she writes:

[Paranoia] has by now candidly become less a diagnosis than a prescription. In a world where no one need be delusional to find evidence of systemic oppression, to theorize out of anything but a paranoid critical stance has come to seem naïve, pious, or complaisant (p. 125).

Following Melanie Klein, Sedgwick writes of paranoia as a relational stance that works to anticipate, generalize, and expose in order to avoid surprises and humiliation. In turn it has a "mushrooming, self-confirming strength" (p. 136) that "seems to grow like a crystal in a hypersaturated solution" and "circumscribes its potential as a medium of political or cultural struggle" (p. 130); a warning that has particular cadence in the context of a scholar-activist project to document and disrupt the circulation of suspicion.

Concerned, ultimately, that "paranoid readings" require a disarticulation, refusal, and/or misrecognition of ways of knowing that are less oriented around suspicion, Sedgwick calls for critical scholars to also do "reparative readings" that weave materials with hope, thereby welcoming surprise.

To read from a reparative position is to surrender the knowing, paranoid, determination that no horror, however apparently unthinkable, shall ever come to the reader as new; to a reparatively positioned reader, it can seem realistic and necessary to experience surprise. 
Because there can be terrible surprises, however there can also be good ones. (p. 146, her italics).

For Sedgwick, then, to be open to surprise is to counter dominant logics of suspicion as well as witness "the queer possibility that yesterday, today, and tomorrow don't have to proceed in lockstep" (p. 146).

And to do so she recommends that we craft multiple, localized knowledges that "do justice to a wide affective range" (p. 145). Indeed, freed from the disciplining of academic publication, Watching Floyd allowed me to not only construct a highly situated account of the trial but to communicate this in ways that move people. As Fine (2006) writes,

Most research is written with an "as if" contract assumed between researcher and audience-I'm objective and you're objective; we're both "watching" society in the making; I won't discomfort, only inform, you. As with some pieces of art or performances, we may think about writing research in ways that move readers to think through implications, actions, collusion, social responsibility, and social imagination.

Folding in stories, feelings, co-incidences, dreams, poetics, imagery, and metaphor that were activated by my being there, I could experiment with substance and form in an attempt to affect readers as well as disrupt the borders of "reason" and "evidence" usually patrolled by the criminal justice system.

This disruption was partly because such modes of representation do not seek to document the world "as it is" so much as move with its complexities and mysteries. Minh-ha (1989) writes of how "he" seeks meaning by "forcing entry or breaking something open", and this is "typical of a mentality that proves incapable of touching the living thing without crushing its delicateness" (p. 49). Instead, counter-colonial scholarship requires a respect for opacity:

And I am profoundly indifferent to his way of theorizing - of piercing, as he often claims, through the sediments of psychological and epistemological 'depths'. I may stubbornly turn around a foreign thing or turn it round to play with it, but I respect its realm of opaqueness. (p. 48) 
Minh-ha's respect resonates with how contemporary artists approach archives. Coming with a legacy of embracing the archive as a potential agent of oppression and liberation, these practitioners aim not to "produce verifiable knowledge" but "engage in a series of ruminative gestures that give rise to non-definitive narratives and tentative forms of suppositional knowledge" (Downey, 2015, p. 14).

This kind of practice - wildly different from my positivist ancestry - invites an audience to not passively receive information so much as actively participate in the making and remaking of meanings, questions, and possibilities. Indeed, following Jacques Derrida, Downey continues that the archive is a radically unstable form of inscription that is "haunted by the moment of writing and the traces of its own ontological coming into being" (p. 38). It thus presents us with the very means of "its own indelible vulnerability to reinterpretation if not its fallibility as a document” (p. 38), creating “epistemological fissures" that can be, in Downey's words, "productive apertures". In tis way the archive is a "reality in waiting", one made by "an unreliable archivist - a nodal point for distilling the essence and ambivalence of the archive into, on one hand, a form of radical uncertainty and, on the other, a call to action" (p. 37). The archive, then, is "far from epistemically stable, historically fixed or hermeneutically coherent", but rather "a contingent, fortuitous and co-dependent moment that promotes conjectural possibility, potentiality and uncertainty" (p. 27).

And creating alternative archival forms is one way to seize this instability and insert "forms of contingency and radical possibility into the archive that sees it projected onto future rather than historical probabilities" (p. 14). Perhaps, then, the reflexivity demanded in Watching Floyd created conditions of instability that opened up the possibilities on trial. In his 2012 book, The Year of Dreaming Dangerously, Slavoj Zizek (2012) contemplates the contemporary revival 
of radical emancipatory politics, reading their related "outbursts" - from the Arab Spring to Occupy Wall Street - as "signs from the future":

Instead of analyzing them as part of the continuum of past and present, we should bring in the perspective of the future, taking them as limited, distorted (sometimes even perverted) fragments of a utopian future that lies dormant in the present as its hidden potential. (p. 128)

It follows that, "one should learn the art of recognizing, from an engaged subjective position, elements which are here, in our space, but whose time is the emancipated future" (p. 128). This kind of "watching", Zizek argues, is a technique in, of, and for revolution.

Indeed, equipped with what Zizek calls a "desire to see", two extracts particularly stand out from the two accounts above as moments in Watching Floyd "in which everything seems possible" (p. 70).

So you can imagine my joy today, when the court was packed with queers. The large and exceptionally punctual crowd could not have been more timely and needed; reminding us that gender circulates with race through the prison industrial complex. (Day 7)

A little shaken, the Judge asked the court for a couple of minutes after the NYPD's hired goons had left. Her skinny older frame wrapped in a black robe up high behind the bench, it felt like she had re-entered her body after rising up. And we spectators sat there stunned, and impressed. The officers will come in on Monday. (Day 21)

These extracts contain moments that collided with the spectatorship of Watching Floyd. Struck with a feeling of joy and shock, an experience of unexpected bodies and power, they felt expansive. They were moments of hesitation and anticipation, of the courtroom holding its breath; we sighed, gasped or laughed together, looked one another in the eye, wondered what was going to happen. An openness that depended on my being in the courtroom and becoming with the archive, cultivating an unstable space of bodies, surprise, and encounter that, together, welcomed time-traveling - a co-constituted glimmer of a court from the future.

Zizek's call for attending to such signs is guided by the two words for "future" in French: 
Radical archiving as social psychology from the future

futur and avenir. The former is the continuation of the present, the latter, "points to a more radical break, a discontinuity with the present - avenir is what is to come (a venir), not just what will be" (p. 134). He thus argues that, "the way to combat the catastrophe [of neoliberalism] is through acts that interrupt this drifting towards the catastrophic 'fixed point' and take upon themselves the risk of giving birth to some radical Otherness "to come"” (p. 134). Could, then, the affective collisions within Watching Floyd speak of avenir - a radical Otherness where "the system" is undoing itself, where "the people" are participants (not spectators), where the borders around "reason" and "evidence" are breached?

If so, then perhaps Watching Floyd performs a sort of "reflexive withdrawal", one that "does not entail a retreat into inactivity, but the opening up of a space for radical change" (p. 111). Such an opening is all the more urgent when watching a trial on "stop and frisk". Albeit happening in the name of "peace", "criminal justice" in the US has historically worked to cast a bleached think-net over experiences of racial injustice, thereby allowing the continuation of its normative violence. As Zizek argues, to accept a given peace process is to, "already endorse the position of the one in whose interests it is to have peace under the present conditions of the occupation" (p. 37, his emphasis). The "true issue", according to Zizek, is thus not peace - it is liberation. In this case, from the post $9 / 11$ neoliberal security state that is continually re-inscribed through both the racist policing on trial and the court itself. It follows that I could not simply document the proceedings; I had to disturb its roots - in content, in form, and in temporality.

\section{Bearing Witness}

Floyd led to a court ordered judgment for an independent monitor to implement a series of reforms to ensure that the NYPD no longer use race as a proxy for crime and engage in a joint 
Radical archiving as social psychology from the future

remedial process that brings affected communities, elected officials, the NYPD, and other stakeholders together to collaboratively reform "stop and frisk" as well as provide a forum for a broader conversation about unfair policing practices (Zamani, 2015). However, nearly two years on, and there is no confirmation that the NYPD is compliant with these orders. To the contrary, it has continued its overly aggressive and discriminatory enforcement of minor infractions and low-level offenses, use of excessive force, and insufficient disciplinary policies and procedures, with a disproportionate impact on communities of color (Zamani, 2015).

Sitting on a courtroom bench straddling the scholar-activist hyphen, watching, timetraveling: I wonder if something missing from these remedies is a vision of how policing could be. Zizek (2012) points out that any signs from the future "come from a place that will become actual only if we follow these signs" (p. 129). And this following comes in the form of questions; to do radical archiving is to embrace what Isabelle Stengers (2011) calls a "culture of interstices", a place of fertile fissures that "open a human collectivity to an outside whose intrusion suspends habitual social functioning" (p. 328), that invite us to ask, Is this really all there is? Thus, rather than being used to enclose possibility, an archive might be built as a different kind of wall; one made not of cement, so much as dry stones.

Cement rejects the interstices in which the weed grows that will one day crack it open. The dry stones, for their part, can of course be displaced, and the weed that displaces them might certainly be tempted to abstract from the fact that without the stone the earth in which it grows would not have held. But the wall of dry stones is not defined against the interstices; the latter belong to it just as much as the stones that make it up. (p. 274)

Constructed by Stengers, this wall offers a vision for social psychologists interested in taking on archiving as a radical practice; one on the lookout for "the green shoot that cracks the rock" - to borrow a line from the poetry of Gloria Anzaldúa (1987, p. 105).

Returning, then, to Fine (2006): a social psychology from the future aims for 
"provocative generalizability". That is, "the extent to which a piece of research provokes readers, across contexts, to generalize to 'worlds not yet,' in the language of Maxine Greene; to rethink and reimagine current arrangements" (p. 98). Fine argues that we need to move our findings "toward that which is not yet imagined, not yet in practice, not yet in sight" thus inviting us to considering "what might be, rather than only understanding (or naturalizing) what is" (p. 100). This capacity to collectively witness emancipatory possibility in present experiences belies a commitment that is especially needed within contemporary conditions. The neoliberal security state encourages us to not only suspect each other, but also the future; the post-9/11 "war on terror" is effectively a war on imagination. Bearing witness must not only be critical, it must be creative. And radical archiving offers one such way to time-travel; releasing the archive from its role as a passive object of inquiry, inviting it instead to be an active, unruly companion in our journey towards a response-able social psychology, one that also has roots that are of the future, beckoning.

\section{References}

Abu-Lughod, L. (2002). Do Muslim women really need saving: Anthropological reflections on cultural relativism and its others. American Anthropologist, 104(3): 783-790.

Alexander, M. (2010). The New Jim Crow: Mass Incarceration in the Age of Colorblindness. New York: The New Press.

Anzaldúa, G. (1987) Borderlands La Frontera: The New Mestiza. San Francisco: Aunt Lute Books.

Apfelbaum, E. (2001). The dread: An essay on communication across cultural boundaries. International Journal of Critical Psychology, 4: 19-34. 
Browne-Marshall, G. (2013). Stop and frisk: From slave-catchers to NYPD, a legal commentary. Trotter Review, 21(1): Article 9.

Capers, B. (2014). Critical race theory and criminal justice. Ohio State Journal of Criminal Law. 12I(1): $1-7$.

Center for Constitutional Rights (2013). Stopped, seized, and under siege: U.S. government violations of the international covenant on civil and political rights through abusive stop and frisk practices. A shadow report submitted before the U.N. Human Rights Committee. September 2013. Center for Constitutional Rights, New York. http://ccrjustice.org/files/CCR_HRC_ReportSubmission_StopandFrisk_US.

Downey, A. (2015). Dissonant Archives: Contemporary Visual Culture and Contested Narratives in the Middle East. I. B. Tauris \& Co: London and New York.

Fine, M. (2006). Bearing witness: Methods for researching oppression and resistance - a textbook for critical research. Social Justice Research, 19(1): 83-108.

Flinn, A. (2011). Archival activism: Independent and community-led archives, radical public history and the heritage professions. InterActions: UCLA Journal of Education and Information Studies, 7(2), Article 6.

Ganesh, C. \& Ghani, M. (2014). Radical archives. Creative Time Reports, May $27^{\text {th }}$. http://www.radicalarchives.net/ra/

Ghani, M. (2015). What we left (un)finished. Chapter in A. Downey (ed.), Dissonant Archives: Contemporary Visual Culture and Contested Narratives in the Middle East. I. B. Tauris \& Co: London and New York.

Hall, S. (2001). Constituting an archive. Third Text, 54, 89-92.

Hall, S. (2005). Whose heritage? Un-settling "the heritage”, re-imagining the post-nation. In J. 
Radical archiving as social psychology from the future

Littler \& R. Naidoo (Eds.), The politics of heritage: The legacies of “race” (pp. 23-35). London: Routledge.

Liebert, R. J. (2013). Watching Floyd. http://morrisjustice.org/watching-floyd.

Massumi, B. (2010) The future birth of the affective fact: The political ontology of threat. In M. Gregg \& G. Seigworth (Eds), The Affect Theory Reader. London: Duke University Press. Mohanty, C. T. (2003). Feminism Without Borders: Decolonizing Theory, Practicing Solidarity. Durham, NC: Duke University Press.

Pillow, W. (2003). Confession, Catharsis or Cure? Rethinking the uses of reflexivity as methodological power in qualitative inquiry. International Journal of Qualitative Studies in Education, 16(2): 175-196.

Sedgwick, E. (2003). Touching Feeling: Affect, Pedagogy, Perfomativity. Berkley, CA: Duke University Press.

Smith, A. (2013). Unsettling the privilege of self-reflexivity. In F. Winddance Twine \& B. Gardener (Eds.), Geographies of Privilege (pp. 263-280). New York, NY: Routledge. Spivak, G. (1988). Can the subaltern speak? In C. Nelson \& L. Grossberg (Eds.), Marxism and the Interpretation of Culture (pp. 271-313). Basingstoke, UK: Macmillan Education.

Stengers, I. (2011) Thinking With Whitehead: A Free and Wild Creation of Ideas. Boston: Harvard Press.

Tuana, N. (2004). Coming to understand: Orgasm and the epistemology of ignorance. Hypatia, 19(1): 194-232.

Zamani, N. (2015). Race and Criminal Justine in the United States. Statement of the Center for Constitutional Rights: Hearing before the InterAmerican Commission on Human Rights.

Zizek, S. (2012). The Year of Dreaming Dangerously. Verso: London, New York. 